\title{
Why Was Hans Denck Thought To Be a Universalist?
}

\author{
by MORWENNA LUDLOW
}

Hans Denck is commonly cited as a universalist. Probably he was not, but there are several reasons why it was easy for his opponents to claim the opposite: his theology admitted the possibility that all people will be saved; his broadly Origenistic conceptions of freedom, divinisation and punishment tempted opponents to attribute Origen's idea of universalism to him; and he so challenged the core beliefs of mainstream Reformation theology that his opponents may have found it difficult to understand how he could claim that God wills all to be saved, Christ died for all and all are free, without being universalist.

I

n his I965 article 'Was Hans Denck a Universalist?' William Klassen takes the then recently-published Mennonite encyclopaedia to task for perpetuating the common but, he asserts, erroneous claim that Hans Denck taught that everybody would be saved. Instead, he argues, a study of Hans Denck's writings reveals no evidence for an unequivocal belief in universal salvation and indeed points to certain indications that such a doctrine would sit very uncomfortably with Denck's other views. ${ }^{1}$

Klassen is correct that a serious scholarly reading of Denck's works provides no definitive evidence that this radical reformer was a universalist; nevertheless, over thirty-five years later the claim continues to be made, most especially in encyclopaedia articles, but also in general surveys of eschatology and occasionally in studies of Denck. ${ }^{2}$ Although such books sometimes have

$H D S=$ Hans Denck Schriften, ed. Georg Baring and Walter Fellmann, Gütersloh 1955-6o; $M Q R=$ Mennonite Quarterly Review

${ }^{1}$ William Klassen, 'Was Hans Denck a universalist?', MQR xxxix (I965), I52-4, citing W. F. Neff's entry 'Universalism', in H. S. Bender and C. H. Smith (eds), Mennonite encyclopedia, Scottsdale, Penn. I959.

2 Works still listing Denck as a universalist include J. M. Lochman, 'Apocatastasis', in E. Fahlbusch and others (eds), The encyclopedia of Christianity, Grand Rapids-Cambridge I999 (trans. of E. Fahlbusch and others [eds], Evangelisches Kirchenlexikon, Göttingen i986); Werner Packull, 'Hans Denck', in Gerhard Krause and Gerhard Müller (eds), Theologische Realenzyklopädie, Berlin I98I; 'Hans Denck', in F. W. Bautz (ed.), Biographisch-Bibliographisches Kirchenlexikon, Hamm, Westfalen 1975; Hans Schwarz, Eschatology, Grand Rapids-Cambridge 2000, 34I. Some other recent studies are more cautious: whereas the article on Hans Denck in 
a tendency to reproduce the errors of their predecessors, this cannot be the only explanation: clearly, in the case of Hans Denck the charge of universalism sticks particularly firmly. So one needs to ask why the accusation was made and why it carried such conviction. Consequently, this paper will attempt not only to investigate the claim of Klassen and others that Denck was not a universalist, but it will also try to explain why Denck was thought - and is still often thought - to be one.

In part, the aim of this paper is thus to correct the historical record. But the question is of wider historical and theological importance than it might at first seem. Denck was a relatively minor, albeit impressive, figure in the Reformation; universalism too is little more than a doctrinal footnote if it is reduced simply to the idea that the damned or the devil will be saved. However, this paper will show that Denck's views on salvation, grace and free will - which were what drew the accusations of universalism - struck at the heart of the theology of the magisterial Reformers and seemed to epitomise what they found most alarming about the teachings of the radical Reformers. Although the charge has clung to Denck with particular tenacity, the fact that some other radical reformers have been labelled as universalists suggests that his soteriology was not uncommon. Certainly, several others had views that opened up the possibility that all might be saved, even though they did not predict that this would be the actual outcome. ${ }^{3}$ Accusations of universalism made against the radical Reformers are thus not just arguments about a narrow doctrinal point, but are illustrative of a more general clash of theological systems.

In answering these issues this article will focus on Denck's written works. There are several contemporary documents which accuse Denck of universalism, but there is no reliable evidence beyond Denck's own written words with which to assess those accusations. If Denck ever preached universal salvation without writing it down we have no detailed narrative account of it. Furthermore, the allegations invariably come from Denck's enemies and the term 'universalist' has been a convenient theological insult ever since a form of Origenist universalism was anathematised at the Fifth Ecumenical Council

the second edition of Josef Höfer and Karl Rahner (eds), Lexikon fir Theologie und Kirche, Freiburg $1957^{-68}$, claims that he was a universalist, that in the third edition (edited by Walter Kasper and others, Freiburg 1993) does not. A detailed examination of Denck's theology concludes that 'it appears that Denck found the doctrine of eternal damnation difficult to defend as the bottom line of Heilsgeschichte': The spiritual legacy of Hans Denck: interpretation and translation of key texts, ed. and trans. Clarence Bauman, Leiden I99I, 47. Max Schär suggests that Denck taught universalism but did not write it down: Das Nachleben des Origenes im Zeitalten des Humanismus, Basle-Stuttgart 1979, 297.

${ }^{3}$ George Hunstanton Williams claims that Denck, Ziegler, Bader and Pocquet were all believed to have argued for the possibility of the salvation of demons; more generally, he presents several characteristics of radical theology that tend in the direction of universalism: The radical Reformation, London i962, 832-45. 
in 553. Consequently, this article will attempt to identify those aspects of Denck's theology which might have suggested the idea of universal salvation to his audience or which are consonant with the idea of universal salvation. In doing so, it will assume that one can read Denck's writings as a coherent corpus: although some have suggested a development in his works, noting possible changes in stance after Denck's rebaptism or in his final so-called 'recantation', this is highly debatable. Denck's works span a period of less than three years and show little change regarding central theological ideas, although a few subtle alterations in his attitude to the sacraments, or to the relation between Church and State can be detected.

Finally, it should be stressed that by 'universalism' I mean the assertion that it is certain that eventually all people will be saved. This is somewhat different from the claim that God wills all people to be saved, or the view that Christ's death was sufficient for the salvation of all people, or the belief that it is possible that all people will be saved. One of the claims of this paper, in fact, will be that these different claims became confused in the debate surrounding Hans Denck.

First, however, let us turn to the terms of the original accusations. The most specific is the account of Denck's teaching recorded by Johannes Kessler whilst Denck was staying in St Gall in 1525 :

[Denck] taught that no man, even if he were to be found in hell, would be lost forever, indeed not even the devil; but after an ordained time, all would be saved; and when Scripture talks of eternal fire, that in fact only means a certain time. He also held other similar teachings of Origen which have been condemned by many believers as heresy. ${ }^{4}$

This is echoed - perhaps a little more cautiously - by Vadian in a letter to Zwiccius:

[Denck] so misused his mind that he defended with all efforts the opinion of Origen concerning the liberation and salvation of those who are condemned. The bountiful love of our God was praised so much ... that he seemed to give hope even to the most wicked and most hopeless people that they would obtain salvation, which would be granted to them someday however distant it might be. ${ }^{5}$

The other important statement comes from Bucer:

And after this, though [Denck and his followers] also cast many holy and elect members of Christ out of the Kingdom of God, they maintain that if

${ }^{4}$ Johannes Kessler, Sabbata, ed. Emil Egli, St Gall I902, I5I-2, trans. by Jan J. Kiwiet as 'The life of Hans Denck', MQR xxxi (I957), 242.

5 'ita abusus est ingenio, ut Origenis opinionem de liberandis olim salvandisque damnatis, magno conatu defenderet ...\& amplissima dei nostri misericordia ita collaudata, ut spem facere vel improbissimis \& perditissimis hominibus videretur salutis assequendae, quae die aliqua quantumvis longa sibi esset obventura': D. Foachimi Vadiani ad D. Foannem Zuiccium epistola, Zürich I540, fo. I9r-v; Kiwiet, 'Life of Hans Denck', 242. 
they would only cry out to heaven once, devils and the damned would finally be saved. ${ }^{6}$

Although this does not of itself strictly entail universal salvation (since some are 'cast out' of the kingdom), by implication it suggests that if even the devils will be saved, all people will eventually find salvation. The removal of some from the Kingdom may simply suggest that the categories of the elect and the damned are broken down in Denck's thought. Most importantly, the writing - like Kessler's accusation - casts Denck's alleged universalism in Origenistic terms: Origen's doctrine was probably most notorious because it was thought to include the salvation of the devil. ${ }^{7}$ This particular aspect of the rhetoric against Denck will be examined later.

How do these claims match up to Denck's own writings? While there are no clear declarations that God will save all people or that even the devil will be saved, there are some statements which might be seen as tending in that direction. First one must note that Denck stresses God's universal saving will: sometimes quoting the Bible to back this claim up (I Timothy ii.4; 2 Peter iii.9), at other times stressing that God is pure love and that it is the nature of love to want to be united with all. ${ }^{8} \mathrm{He}$ acknowledges that there are apparent contradictions in Scripture: for example, 'those whom he called he also justified' (Romans viii.3o), but 'many are called but few are chosen' (Matthew xx.I6). ${ }^{\mathbf{9}}$ However, he criticises those who resolve those contradictions in favour of the doctrine of double predestination: they assert that whereas God's revealed will is to save all people, his hidden will is to elect some to salvation and others to damnation. Against this, Denck stresses that God's will is what it is revealed to be and that it has been so from eternity:

He grants that all people be called and offers his mercy to everyone with wholehearted earnestness and desires truly to accomplish all he promised. Is it not therefore deceitful when our scribal authorities say that he invites someone to be called to Communion but that it is not his will that one come? ... He would not

6 Martin Bucer, Getrewe warnung in Martin Bucers deutsche Schriften, II: Schriften der Fahre I524-I528, ed. Robert Stupperich, Gütersloh-Paris 1962, 235, trans. by Alvin Beachy in The concept of grace in the radical Reformation, Nieuwkoop I977, I6.

7 Origen himself in fact denied this claim, which was made famous by the dispute between Jerome and Rufinus: Henri Crouzel, 'L'Hadès et la géhenne selon Origène', Gregorianum lix (1978), 327 .

${ }_{8}$ Was geredt sei, das die Schrift sagt, II5 (HDS, 46); Ordnung Gottes, $2 \mathrm{I}_{5}$ (HDS, 90); Von der waren Liebe, I83 (HDS, 76): 'Love is a spiritual power by which one becomes united or desires to become united with someone else. ... Where love is pure and impartial to none, it reaches out and desires to be united with everyone ... for it can never be satisfied enough by all lovers'. All citations from Denck's works are from the Bauman edition which provides an English translation in parallel to an exact reprint of $H D S$, the standard German edition. In this article, references to $H D S$ are given in parentheses after the page number in Bauman's translation.

${ }^{9}$ Wer die Wahrheit wahrlich lieb hat, 167 (HDS, 69). 
grant someone grace and secretly wish to withdraw it again; it is not so that he inspires repentance of sins (der sünden rew) in us and secretly prepares us for hell, for in all his gifts he is ever constant and genuine (steet und warhafftig). ${ }^{\mathbf{1 0}}$

It is evident that some of Denck's opponents felt that since God chose only some people Christ died for them alone. Denck rejects this conclusion as emphatically as he rejects its premise:

You might say, 'Yes, he may well have died out of love, but not for all, but only for some (vile).' Answer: since love in him was perfect, which hates or envies no one, but receives everyone (yederman aufnymbt), though we are all his enemies, he could not exclude anyone ... Should it not be true, nonetheless, that he died for all even though not all were saved ?1 $^{11}$

Thus Denck argues that not only does God will all to be saved but that 'to that end he also set forth a means, prepared from eternity, by which humankind would be saved even as they had been created, that is, his Word'. ${ }^{12}$ In other words, the will of the Father is perfectly accomplished in and unified with the action of the Son: any disjunction between God's universal saving will and the scope of the salvation effected through his Word would suggest that God was either impotent or paradoxically indecisive.

In what way has God the Father acted in his Word in order that all people can be saved? Hans Denck's answer is two-fold. First he famously witnesses to a profound inner experience of God: 'I ... sense ... something within me that powerfully resists my inborn wilfulness and points me to a life or sanctity which appears as impossible to attain as it seems inconceivable for my body to ascend the visible heaven[s]. ${ }^{13}$ This Denck calls 'the truth in me', or 'the mediator' and, occasionally, 'the Word', 'the Spirit' or 'a divine spark'. ${ }^{14}$ He is quite clear that God is present in this way in all people, even though they may not recognise it:

This attestation (gezeugnuss) is in all people and proclaims to each one in particular, according to how one hears him. Whoever wishes to excuse himself that he does not hear is a liar, for he blinds himself, though God has given him good vision. For this Lamb has been from the beginning of the world and remains to the end a mediator (ain mitler) between God and people. ${ }^{15}$

${ }^{10}$ Was geredt sei, II5 (HDS, 46); see also ibid. 99 (HDS, 38). For the Lutheran doctrine of God's hidden and revealed will see, for example, Paul Althaus, The theology of Martin Luther, Philadelphia I966, 275-6.

11 Was geredt sei, IOI (HDS, 39) (in this case only the translation is from Selected writings of Hans Denck, $1500-1527$, ed. E. J. Furcha, Lewiston-Lampeter I989, 201).

12 Was geredt sei, 99 (HDS, 38). ${ }^{13}$ Bekenntnis für den Rat zu Nürnberg, 55 (HDS, 20).

14 Jan J. Kiwiet, 'The theology of Hans Denck', $M Q R$ xxxii (1958), 8.

15 Was geredt sei, 89 (HDS, 33). See also ibid. Ior (HDS, 39): "[the Word] is so near to all persons (however much they have wanted to reject God) that they can easily receive it in simply returning to God'. 
Denck emphasises that this means all people, including pagans and Jews, and indeed all creation, 'the dumb, deaf and blind, indeed, unreasoning animals, yes, foliage and grass, stone and wood, heaven and earth, and all that is therein - so that they may hear and do his will' ${ }^{16}$

For his opponents the extremely uncomfortable corollary of this is that it diminishes the importance of Scripture. Denck appears to have been challenged frequently on this point, for in his 'Recantation' he feels the need to defend himself: 'Holy Scripture I hold above all human treasure but not as high as the Word of God that is living, powerful and eternal ... Therefore, salvation is not bound to Scripture however useful and good it might be in furthering it. ${ }^{17}$ Despite the fact that he was frequently accused of doing the opposite, his writings always stress the power of God in salvation, in order to free it from being restricted to human means. This is coupled with a genuine yearning that all people might come to know God, which he thinks would be impossible if salvation were directly linked with human accounts of revelation - as opposed to the revelation itself:

Thus a person who is chosen of God (der von Gott erwelet ist) can be saved without preaching or Scripture. Not that one should therefore hear no preaching nor read any Scripture, but [rather it is not the case that] none of the illiterate (ungelerten) could be saved because they could not read and (perhaps many entire cities and lands) since they have no preachers sent by God. ${ }^{18}$

In those circumstances where Scripture is useful, he nevertheless stresses that the Spirit within each person is necessary for its interpretation. For in order to understand the words from God one must know God - he compares this to not being able to understand a letter unless one knows who wrote it. ${ }^{19}$ The Spirit's role in interpretation is particularly important given the fact that Scripture can often appear contradictory. ${ }^{20}$ However, the importance of Scripture is given some foundation in the fact that while the truth within the reader interprets Scripture, Scripture discloses that inner truth to be Christ:

I read it and find in [it] particular testimony (zeïgnuss) which powerfully confirms that just that which thus compels me is Christ whom Scripture testifies to be the Son of the Most High. ${ }^{21}$

This extract shows that although Denck is guilty of blurring the roles of the second and third persons of the Trinity with regard to that truth which is within all people, he cannot justly be accused of denying the divinity of the

${ }^{16}$ Ibid. 99 (HDS, 38). $\quad{ }^{17}$ Widerruf, 25I (HDS, го6). $\quad{ }^{18}$ Ibid.

19 Vom Gesetz Gottes, I49, I53 (HDS, 6r, 63). See also Bekenntnis, 57 (HDS, 21): 'Inasmuch as I presume [to discern] Scripture in my own power, I understand nothing. As much as that [truth] compels me, that much I thus comprehend, not through merit, but by grace. By nature I cannot, indeed, believe the Scripture.'

20 Wer die Wahrheit, ${ }^{6} 6_{5}$ (HDS, 68).

21 Bekenntnis, 57 (HDS, 2I). 
Word of God. ${ }^{22}$ As several commentators have pointed out, the truth within is not some part of human nature which is given special grace, but it is indeed God. ${ }^{23}$ Denck's central theological assumption is that 'man could never accept grace without grace'; thus 'God is in all creatures, but not therefore from them but them from him' ${ }^{24}$ The importance of Scripture lies in identifying this internal word as the Word which became flesh.

This raises the crucial question of why the Word needed to become incarnate in Jesus of Nazareth if there is this divine spark in everyone. This is the second part of Denck's answer to how God has acted in the Word to save all people. More specifically, he writes that 'he who wishes to know and to attain true Love, cannot receive it more directly and more easily than through this Jesus Christ ${ }^{25}$ His assumption is that although salvation is not essentially to do with the temporal and spatial context, salvation comes to human beings in that context and thus is most easy for them to appreciate when revealed in a true human being. His soteriology is based on the idea of Christ as a forerunner and of Christians imitating his life of love and selfgiving. Although Denck does assert that 'Christ has done sufficient for the sin of all mankind through his suffering', this is not to be understood as a substitutionary sacrifice made for all people by Christ. ${ }^{26}$ The problem with seeing the atonement in terms of a debt of obedience or punishment owed to God is that one has to explain both why that debt can be paid by someone else and how that payment can be appropriated by the believer. Instead, Denck sees Christ's life and death as the revelation of perfect love, which revelation can be not only understood but followed by others because of the truth already existing in their hearts:

[Christ] has done enough for the whole world and has pioneered the Way which no person could find in order that one might walk therein and come to life. Whoever does not walk the way does not come to life; for him it is in vain. ${ }^{27}$

The 'Way' is sometimes expressed by Denck as the fulfilment of the Law, at other times as leading a life of love; in fact, the two are united: 'one who does not know God cannot love him; one who does not love him, does not keep his commandments and also does not have life ${ }^{2}{ }^{28}$ Christ's suffering, then, is not a substitute for our own, but an example of love to be followed, for true

\footnotetext{
${ }^{22}$ Bauman is correct in asserting that Denck has a 'high christology': The spiritual legacy of Hans Denck, 27, $29 . \quad{ }^{23}$ Kiwiet, 'The theology of Hans Denck', 6, 8.

${ }^{24}$ Was geredt sei, 99, 87 (HDS, 38, 32).

25 Von der waren Liebe, I87 (HDS, 78). See also Was geredt sei, го (HDS, 39): 'You say: If the Word is thus in all persons, why does it need the humanity of Jesus Christ? ... Response: ... That the Word ... became man in Jesus had to be for the reason that mankind both in spirit and in flesh, from within and without, before and after, and in all places, might have testimony.'

26 Widerruf, 25I (HDS, го6). See also Ordnung Gottes, 225 (HDS, 95): Christ 'suffered for all'.

27 Vom Gesetz Gottes, I33 (HDS, 53).

${ }^{28}$ Ibid. I5I $(H D S, 62)$.
} 
love will suffer anything for the beloved. ${ }^{29}$ In Christ, God and humanity were 'so completely united in love' that 'all the suffering of this man is reckoned the suffering of God' ${ }^{30}$ Hence the example before us is not just that of a good man, but of goodness, of love itself and in loving we too can - in a more limited way - become united with God.

Thus for Denck the point of Christ's incarnation is not that through him we are justified and counted as righteous before God; rather, we are enabled through the interaction of his example and his presence within us to live a new life and be transformed. ${ }^{31}$ One of his main concerns, it seems, was that Lutheran doctrine could lead towards antinomianism and a lack of concern for moral behaviour. ${ }^{32}$ Rather, Denck argues, true faith must transform the individual and this transformation will result in good works: 'whoever does not love his brother, certainly does not love God, for he does not keep his commandments' ${ }^{33}$ This emphasis on the transformation of the Christian 'from the root up' contrasts with the Lutheran emphasis on justification. ${ }^{34}$ Rather than saying that the Christian is simul justus et peccator, Denck asserts that 'whoever at one time has truly repented of [sin], is born of God and sins no more' ${ }^{35}$ This emphasis on a union in love with God and on the notion of divinisation has clear antecedents in the Greek Fathers and the mystical tradition stemming from them. ${ }^{36}$ Denck in fact sometimes echoes the Greek Fathers in statements such as 'The Word was in man, in order to divinise him ${ }^{37}$

It is clear then that Denck claims both that God has a universal saving will and that the means of salvation in the Word is sufficient for all people. However, in order to hold a doctrine of universal salvation, one also needs to affirm a third belief: that all people will in fact respond positively to that offer of salvation. This, indeed, is where much of the confusion lies, for Denck's stance regarding this third point is not easy to ascertain. Denck's particular soteriological perspective, with its emphasis on the imitation of Christ, means

29 Von der waren Liebe, $183(H D S, 76)$.

${ }^{30}$ Ibid. 185 (HDS, 77); cf. Ordnung Gottes, 223 (HDS, 94).

31 See Kiwiet, 'The theology of Hans Denck', i I.

${ }^{32}$ See, for example, Beachy, The concept of grace, 30; A. Coutts, Hans Denck, I495-I527: humanist and heretic, Edinburgh I927, I43-4

34 Ibid. I39 (HDS, 56).

33 Vom Gesetz Gottes, I37-9 (HDS, 55-6).

The influence on Denck of the German mystical tradition has been well documented. See, for example, Bauman, The spiritual legacy of Hans Denck, ch. ii; Beachy, The concept of grace, $\mathrm{I} 99$.

${ }_{37}$ 'Es was darumb in den menschen, das es sy vergottet': Was geredt sei, 100 (HDS, 39) (English translation, author's own); cf., on the eucharist, 'He who ... drinks from the invisible chalice the invisible wine ... he becomes drunk and no longer knows anything about himself but through the love of God becomes entirely deified (vergottet) and God in him humanised

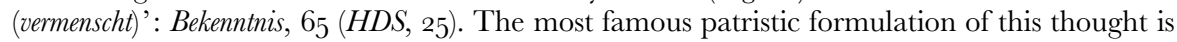
Athanasius' dictum 'for he was made man that we might be made God': De incarnatione 54.3 (Nicene and Post-Nicene Fathers of the Church iv, I99I), 65. 
that faith is inextricable from action and is thus more than intellectual assent or a broad commitment of will. Denck certainly thinks that all people can respond to God in this sense. In a direct challenge to Luther, he asserts that all people are genuinely free to do so:

The Light, the Word of God which is invisible, shines in the hearts of all persons who come into this world, for it is therein from the beginning and gives free power to become a child of God and to inherit the Father's Kingdom to one who receives it (Jn i). For him who does not want it, the Light shines as a judgment and condemnation (gericht und verdammnuss) ( $\mathrm{Jn}$ iii, ix), for it is not becoming for him who desires unconstrained service (2 Cor. ix, Ecclus. xxxv) to compel someone to serve him directly against his will just as he also does not compel anyone to do evil (Ecclus. xv). ${ }^{38}$

This extract also emphasises that it is God's will that freedom is intrinsic to salvation. ${ }^{39}$ This freedom is not destroyed by human sin: although Denck believed that sin was universal (except in Jesus Christ), he denied that it absolutely prevented people from hearing the Word of God in their hearts and obeying it. On the contrary: we hear the Word, but refuse to listen. ${ }^{40}$ Rather than being the complete degeneration of human nature, then, sin is a 'wilfulness' which resists God. Although it is 'inborn', we are still responsible for perpetuating it ourselves. ${ }^{41}$

Thus far, it might appear that Denck is teaching a type of Pelagianism or a theology of works in which the human response to God is met with the gracious reward of salvation. This impression might also be reinforced by the firmly moralistic stance which he takes. However, two notes of caution must be sounded. Although Denck does suggest that individuals are free to turn to God, this turn is clearly a change of heart or mind, a coming to know and love God: it results in, but is not to be identified with, good works. Denck is far from suggesting that God owes people salvation in return for their obedience. Rather, obedience and salvation are both the results of knowing and loving God, for 'one who does not know God cannot love him; one who does not love him, does not keep his commandments and also does not have life' ${ }^{2}{ }^{2}$

Secondly, although people are free to turn to God it is not human freedom alone which is involved in this change of heart: God too is involved. As we saw above, precisely because the word within humans is in fact God, 'salvation is in us but not of us'. ${ }^{43}$ Humans cannot receive grace without grace; they cannot receive God, without somehow containing God. ${ }^{44}$ The truth within us is truly a mediator. ${ }^{45}$ Denck has not, therefore, replaced sola gratia with solum liberum arbitrium; rather he tries to articulate a complex

\footnotetext{
38 Ordnung Gottes, 2 I5 (references included thus in original) (HDS, 9o).

39 See also Was geredt sei, 93 (HDS, 35).

40 Kiwiet, 'The theology of Hans Denck', io-I I.

41 Denck, Bekenntnis, 55 (HDS, 20); Kiwiet, 'The theology of Hans Denck', Io.

42 Vom Gesetz Gottes, I5I (HDS, 62).

43 Was geredt sei, 87 (HDS, 32).

44 Ibid. 99 (HDS, 38). $\quad{ }^{45}$ Kiwiet, 'The theology of Hans Denck', I4.
} 
interweaving of the divine and the human. The emphasis on freedom means that some genuinely human response is involved:

You say: If then salvation (die seligkait) is in me, what do I still lack? Am I not already saved (selig)? Response: No. Why? Because it is not enough that God is in you, but you must be in God. ${ }^{46}$

The problem for Denck is to explain how that can be. He uses the traditional mystical category of submission to God: a category which tries to combine both the active (a person's willing turn to, faith in or love of God) and the passive (allowing God to work through him or her).

[The misunderstanding] lies not with my willing or running, but ... in that one presumes to run straight to heaven in one's own strength; then one falls and runs off track towards the opposite. But when I run in the truth, so that not I but God's Word runs in me, so that I run passively (leydenderweyss), then my running will not be in vain $\ldots{ }^{47}$

Thus the truth about freedom is revealed: in effect Denck distinguishes between freedom of will and the freedom to fulfil one's will. ${ }^{48}$ People have the former at all times, the latter they only have insofar as they are submitted to God. Consequently, sinful humans are both free to will their union with God yet not free to fulfil that will; when they are unified with God, however, they are free, through him, to fulfil their will for that unity, and yet not free, because they are totally submitted to him:

The more a man approaches and becomes conformed to his origin in creation, the more free he is; the deeper he sinks into condemnation, the more captive he is (Matt. $\mathrm{v}, \mathrm{xviii}$. But, however free he is, he can nevertheless not do the good other than through suffering (Phil. ii); however captive he may be, he is still free to suffer what the Word performs in him (Matt. xxiii). ${ }^{49}$

In this way, Denck tries to avoid both extremes: it is 'obvious vainglory and foolish security' to think that one is so free that one can save oneself; it is 'insidious humility' to assume that one is so unable to do anything that one fails even to submit oneself to God. ${ }^{\mathbf{5 0}}$ That humans are free to respond is testified to by the fact that some do not: their freedom is demonstrated not only by their ability to reject God, but also by the fact that they are punished for it, since a good and just God cannot punish those who are not responsible

46 Was geredt sei, 87 (HDS, 32).

47 Ibid.

48 Kiwiet, 'The theology of Hans Denck', I4-I5.

49 'Wievil der mensch seins ursprungs der schöpffung nähner und ähnlicher ist, sovil ist er freier, wieviel er tieffer im verdammnuss ligt, sovil ist er gefangen, Matthei 5.I8. Wie frei er aber ist, so kan er doch das gut nit anders thun dann leidenderweiss, Phil.2; wie gefangen er ist, so mag er doch frei leiden, was das wort in im thut, Matth. 23': Ordnung Gottes, 227 (HDS, 96).

50 Ordnung Gottes, 227 (HDS, 96). 
for their crimes. ${ }^{51}$ On this basis Denck articulates a doctrine of sin being its own punishment: its after-effects cause the sinner suffering and are designed by God to turn him or her away from sin. Thus divine punishment is seen as reformative, not retributive. ${ }^{52}$ Hell, consequently, is sometimes interpreted as a feeling of complete abandonment, followed by (or resulting in) an experience of God's mercy which leads to a desire for God. ${ }^{53}$ Similarly, if God hardens people's hearts it is to turn them to repentance. ${ }^{54}$

The crucial question, therefore, is whether this hell is always temporary. In some places Denck certainly sounds as if he thinks that it is; for example, 'even hell is exposed before the Lord and damnation has no covering (Job xxvi)'. ${ }^{55}$ Just a few lines later, however, Denck appears to suggest that hell can become a permanent state for a hardened recidivist: 'As soon as a person becomes aware of the Word, he is once again free ( $\mathrm{Jn}$ viii) to continue in his wickedness or to sacrifice himself in suffering. The more he resists suffering, the more he condemns himself until he finally submerges himself in death ${ }^{\mathbf{5 6}}$ There are other passages where Denck implies that some people will not be saved, again also stressing that the fate of the lost is due to the misuse of their own freedom. For example:

But he who for the sake of the world forfeits divine freedom will with this 'freedom' be pierced through the ear by Satan his lord at the door of his bondage as testimony that, at this gate, out of free will by his own guilt, his obedience has been apprehended and imprisoned and will remain in all eternity (Ex. xxi, Deut. xv). ${ }^{57}$

Although this extract implies that the devil will survive as the persecutor of the unjust, elsewhere Denck suggests that the devil, as the epitome of evil, will simply cease to exist. ${ }^{58}$ Despite these passages, Denck is in fact not very interested in the question of whether the devil himself will be saved. The important point is that he is interested in the very real possibility of trapping

51 This is the assumption behind the whole of Was geredt sei; see especially 103-5 (HDS, 40-I). See also Ordnung Gottes, 2 I9 (HDS, 92), where Denck imagines the Word saying to sinners: 'You have brought all this upon yourselves, therefore you should not blame anyone else and suffer what you yourselves have chosen and suffer fairly and rightly.'

${ }_{52}$ Was geredt sei, 8I-3 (HDS, 29-30); cf. Bekenntnis, 6I (HDS, 23): 'the Lord leads down into hell and up again' ('Der herre füret hinab in die helle und wider herauff').

${ }^{53}$ Ordnung Gottes, 22I (HDS, 93). $\quad{ }^{54}$ Was geredt sei, II3 (HDS, 45).

55 Ordnung Gottes, 219 (HDS, 92). $\quad{ }^{56}$ Ibid.

${ }^{57}$ Ibid. 239-4I (HDS, I02). See also ibid. 225 (HDS, 95); Was geredt sei, I07 (HDS, 42): 'For whom God has received in faith he can and will reject (verwerffen) if he does not remain in faith'; and Was geredt sei, i 7 (HDS, 47): 'And if you do not return while the Lord grants you opportunity, you will have portion with him who from the beginning has conceived and given birth to the lie on his own, whose inheritance is the gnawing worm that no-one can kill and the eternal fire that no one can extinguish' ('Und so ir nit widerkeret, dieweil eüch der herr raum gibt, werdet ir tail haben mit dem, der die lugen anfenngklich auss seinem aigenthumb empfangen und geboren hat, welchs erb ist der nagend wurm, den nyemandt tödten, und das ewig fewr, das nyemandt löschen kan').

58 Ordnung Gottes, 23I (HDS, 98). 
oneself in sin. He must therefore think that it is possible, if not likely, that some people will not be saved and this would make it very difficult for Denck to declare a confident belief in universal salvation.

Two other reasons can also be put forward to support the claim that Denck was not a universalist. The first of these is suggested by William Klassen. He asserts that 'a thoroughgoing universalist position would ... have violated [Denck's] stress on the freedom of the will' ${ }^{59}$ Logically speaking, of course, this is strictly correct - for if humans are really free to choose their destiny, no one can determine who will be saved. It may be that God knows who will be saved, but, according to Denck, foreknowledge is not predestination. However, there is an interesting parallel with Origen's thought here. Origen's concept of salvation is reliant on an even more emphatic doctrine of human freedom than Denck's is, and yet he seems to be committed to a belief that eventually everyone will be saved. ${ }^{60}$ The important word here is 'eventually': Origen assumes that if one takes long periods of post-mortem punishment and education into account eventually all people will freely choose God. He acknowledges the logical problem, but asserts that only God knows how universal salvation will be achieved in a way which is consistent with 'the preservation of free will in all rational creatures'. ${ }^{61}$ In fact, Origen's view is based not just on faith, but also on certain assumptions about anthropology and on a relatively optimistic account of the effect of the fall. Furthermore, he assumes that everyone who chooses God will become the sort of person who will always freely want to be with God-making the possibility of future falls void. ${ }^{62}$

This comparison with Origen suggests that, judging on the issue of freedom alone, one cannot rule out the possibility that Denck believed in universal salvation, for he too could have thought that humans are created in such a way that eventually they will all choose to turn to God. However, the further reason to think Denck was not a universalist is that he writes very little about the after-life and seemingly nothing about divine punishments after death: God's pedagogical punishments and the 'hell' he describes are all states before death. This emphasis might have a rhetorical function: it is perhaps easier to enjoin repentance on people if they fear an immediate punishment (or if you can persuade them that their present miserable state is a punishment) than if you are simply promising them punishment after death - particularly if you also claim that eventually all people can or will be saved. Alternatively, it might be because Denck thought that the fate of each person

${ }^{59}$ Klassen, 'Was Hans Denck a universalist?', I53.

${ }^{60}$ Most commentators conclude that Origen did assert universal salvation, although Crouzel expresses some doubts, partly on the grounds of Origen's doctrine of human free will:

'L'Hadès et la géhenne', 325 .

${ }^{61}$ Origen, De principiis iii.6.3, ed. and trans. G. W. Butterworth, Gloucester, Minn. I973.

62 See Brian Daley, The hope of the early Church, Cambridge I99I, $5^{8}$. 
is sealed in this life. Jan Kiwiet (whose account of Denck's theology is perhaps the most even-handed available) bases his conclusion on the last assumption: 'Denck speaks about the redemption which has happened in the past at Calvary and about obedience in the present time, while Origen was thinking about the long processes of testing and purification after this life, which would eventually result in a general atonement [i.e. universal salvation]. ${ }^{\prime 63}$ This difference in perspective would also explain Denck's insistence that people can be saved without a revelation of the incarnate Jesus Christ either directly or through preaching or Scripture, because they can still know Christ the Word in their hearts: Denck's concern for the universality of divine revelation becomes much more comprehensible in a belief-system where there are no second chances after death. However, precisely because there are no such second chances it would be foolhardy to suggest that all people will in fact be saved: not only are there people whose behaviour seems to lack all evidence of having been saved by God, but the shortening of the time-scale makes it inherently less likely that all people will freely choose God. Indeed, some would say that this outcome becomes very unlikely indeed. ${ }^{64}$

On these grounds, it seems very probable that Hans Denck was not a universalist in the sense of asserting that all people will certainly be saved. However, there are several reasons why this view is likely to have been attributed to him. First, although Denck's writings do not appear to follow Origen's eschatology, they do recall that of Origen in several ways. Besides the claim that God wills all to be saved and the connected assertion that God's justice and wrath must be subject or harmonious with his love and mercy, both theologians see human freedom as central to the divine plan. ${ }^{65}$ In fact, only on the assumption of human freedom can God's wrath in punishment be understood and justified. Furthermore, both theologians' conceptions of the transformation of the believer through obedience to and the imitation of Christ also rely on the assumption of human free will. For example, Origen's own emphasis on the transformative imitation of Christ is strikingly similar to Denck's version:

For Christians see that with Jesus human and divine began to be woven together, so that by fellowship with divinity human nature might become divine, not only in Jesus, but also in all those who believe and go on to undertake the life which Jesus

63 Kiwiet, 'The life of Hans Denck', 243. Of course it is not true that Origen had no interest at all in the behaviour and transformation of Christians in this life, nor that he ignored the possibility of God's punishment in this life.

${ }^{64}$ Oddly, Roerich claims that Denck thinks both that 'the process of individual purification takes place in the present life' and that 'the reward is for everyone without exception', without explaining how this might be possible: Gustave Guillaume Roehrich, Essay on the life, the writings and the doctrines of the anabaptist Hans Denck, Lanham, MD I983, 20.

${ }^{65}$ Origen De principiis ii.5.3; Homilies on Jeremiah iv.4, in Origène, Homélies sur férémie, ed. Pierre Nautin, SC ccxxxviii, Paris 1977. 
taught, the life which leads everyone who lives according to Jesus' commandments to friendship with God and fellowship with Jesus. ${ }^{\mathbf{6 6}}$

Finally, although both men can be accused of over-emphasising the human role in salvation, in fact each theologian attempts to balance it with divine grace. $^{67}$

Unfortunately, although the broad structure of Denck's life has been established, we do not know enough to be able to say whether he read Origen himself. The study of Origen was popular in humanist circles, particularly those closely linked with Erasmus. Denck was clearly influenced by the humanism in Basle where he studied in 1522 and although he may never have met Erasmus the specific influence of that great scholar on Denck is quite clear, particularly with regard to Denck's hermeneutics and his concept of freedom. ${ }^{68}$ The fact that Denck studied Hebrew as well as Latin and Greek may be significant, for Origen was a scholarly ideal for Christian humanists in this respect, since he was the first great Christian scholar of Hebrew. ${ }^{69}$ When Denck undertook the first translation of the prophets from Hebrew into German he cannot have been unaware of Origen's influence. Although further textual study might be able to establish that the theological resonances indicated in the previous paragraph are also close literary echoes, it is already very probable that Denck was influenced by Origen, whether directly or indirectly.

What is crucial, then, is that enough of Origen's influence had filtered into Denck's theology for him to be accused of holding even those of Origen's doctrines that he did not formally espouse, and that his opponents knew enough about Origen to make that accusation. Jacques Merlin's I5I2 edition of Origen's complete works had an enormous effect in making his writings more accessible in western Europe (six more editions appeared in the following twenty-four years). Those German humanists of the period who were sympathetic to Origen were attracted to him as a scholar, exegete and preacher. ${ }^{70}$ Although Origen's allegorical exegesis was controversial, it was accepted by many as a way of both taking the text very seriously in itself and allowing it to interact with the reader for his or her spiritual transformation. This positive appreciation of Origen's hermeneutics often went with an acceptance of his anthropology and doctrine of free will - ideas which came

${ }^{66}$ Idem, Contra Celsum iii.29, ed. and trans. Henry Chadwick, Cambridge 1953, I46.

${ }^{67}$ Idem, De principiis iii.I.I9: 'our perfection does not come to pass without our doing anything and yet it is not completed as a result of our efforts, but God performs the greater part of it'.

68 Thor Hall, 'Possibilities of Erasmian influence on Denck and Hubmaier in their views on the freedom of the will', $M Q R \times x x v$ (I96r), I49-70; Kenneth Davis, 'Erasmus as a progenitor of anabaptist theology and piety', $M Q R$ xlvii (1973), I63-78. Whereas Hall claims Denck and Erasmus met, Kiwiet is doubtful: 'The life of Hans Denck', 234.

69 Schär, Das Nachleben des Origenes, 270. $\quad{ }^{70}$ Ibid. $255^{-63}$. 
to the fore in the controversy between Erasmus and Luther. However, it seems that Origen's effect in Germany at this time, although very important, tended to be restricted to these theological areas. Erasmus and the scholars he influenced were more in the tradition of the medieval monks who stressed Origen's doctrine of the spiritual life, rather than in the mode of the fifteenthand sixteenth-century scholars in Italy who were drawn to Origen's Platonism and more speculative ideas. Hence, for example, although it is clear that Vadian and Bucer knew Origen (at least through Erasmus' works and perhaps more directly) and were not at all ill-disposed to him in principle, they would have been unlikely to sympathise with ideas such as universalism. ${ }^{71}$ On the other hand, as the wording of their criticisms of Denck shows, they knew enough about Origen to suspect that his and Denck's soteriologies were heading in the same direction. In particular, they may have been wary of anything which appeared to suggest that all punishment is temporary: for instance, by the beginning of Denck's literary career Zwingli had already condemned Origen's doctrine of purificatory punishment and the idea that the devils might be saved. ${ }^{72}$ Interest in Origen at the time was so widespread among the intellectual elite that even some of those whose opposition to Origen was more thorough-going would have known enough about his theology to be able to recognise its affinities with Denck's.

The similarities between Origen and Denck, then, were of such unusual strength that they either led people to the erroneous assumption that Denck also taught the doctrine for which Origen was most famous, or else provided his enemies with an excuse for distorting their account of Denck's theology in a convincing manner-so that it appeared indubitably heretical. In particular, it seems that Denck's speculation about purificatory punishment would have made him stand out even amongst enthusiasts for Origen, who tended to be influenced mainly by his ideas on hermeneutics and free will. These conclusions are borne out by the accusations against Denck which were quoted at the beginning of this article. What concerns the writers in particular is the impermanence of God's punishment: 'after a certain time, all would be saved'; 'although the Scriptures prophesy everlasting things, it means nothing else than for a long time'; 'salvation would be granted to them someday however distant it might be'; 'devils and the damned would finally be saved'. Although the apparent specificity of these claims might seem convincing, there are reasons to doubt their accuracy. First, they present a somewhat exaggerated and cliché-prone account of Origen's doctrine, drawing attention, for example, to his argument that the Greek word for 'eternal' means age-long, not everlasting and to the notorious claim that the devils would be saved. ${ }^{73}$ Second, the writers were known opponents of

\footnotetext{
${ }^{71}$ Ibid. $255^{-6 .}$

72 Ibid. 26o.

${ }^{73}$ Crouzel, 'L'Hadès et la géhenne', 320, 326-7.
} 
Denck: although Kessler and Vadian both make an effort to describe Denck's personal character in positive terms, their assessment of his theology cannot be relied upon, because it was implicitly or explicitly opposed to the reform movement with which they were deeply involved in St Gall. ${ }^{74}$ Bucer had an established reputation for arguing against Denck and his associates: he was largely responsible for Denck's expulsion from Strasbourg in ${ }^{1526}$ and published a critique of Denck's and Kautz's views a year later. ${ }^{75}$ Thirdly, universalism was a notorious heresy and belief in it was often held to be destructive of social order and an encouragement to sin: it would therefore be a useful accusation to level at someone associated with the Anabaptists at whom similar accusations were often levelled. Finally, as we have already noted, the claims are not borne out in Denck's own writings. Although there may have been thinkers who believed in universal salvation but did not record the belief for fear of the consequences, it would seem odd for Denck to have preached the doctrine of universal salvation openly (as the accusations imply) yet not write it down.

However, besides his echoing of Origen's theology, a second reason why Denck's opponents might have accused him of universalism is that there was confusion over his claims or, more precisely, an assumption that one or all of them directly entailed universal salvation (and again this could have been due to either genuine confusion or opportunistic distortion). For example, for those theologians who stress God's power and sovereignty the idea that God can will all to be saved and yet might not save all is tantamount to contradiction. Yet Denck clearly believes that God's omnipotence is not threatened by God's own decision to let humans be what they will themselves to be. Secondly, some might think that the claim that Christ died for all entails the claim that all are saved. But this is only a valid conclusion if one also accepts the premise that Christ died just for those whom he saved - which Denck explicitly denies. Finally, if one assumed the hypothesis that only those whom God has chosen for salvation are free, one could argue that if all are free, then all are chosen and thus all are saved; however, such a hypothesis would be a complete misunderstanding of Denck's theology of free will and grace. Freedom is precisely the universal freedom to allow oneself to be chosen and the outcome is not defined. Commentators have noted that any denial of double predestination - by asserting universal freedom - was liable to be interpreted as logically entailing universal salvation. ${ }^{76}$ Indeed this anxiety seems to lie behind the passage from Bucer quoted towards the beginning of this article. However, the denial of double predestination is merely the denial that God has foreordained some to be saved and others to be damned; it is not necessarily the assertion that God has foreordained that

${ }^{74}$ Kiwiet, 'The life of Hans Denck', 242.
76 See, for example, Beachy, The concept of grace, in. 
all will be saved - for that in itself would be a form of predestination, albeit one with a single outcome. ${ }^{77}$

Interestingly, although Denck was accused of being a universalist, it seems that frequently his opponents were more worried about other aspects of his doctrine: Bucer's complaint that Denck denies the uniqueness of Christ and sees him only as an example echoes his complaint to Zwingli that the Anabaptists 'openly refute Scripture and deny the satisfaction of Christ'. ${ }^{78}$ For this reason, the additional charge of universalism is perhaps best seen as a consequence of these other accusations : it is, as we have shown, precisely because Denck challenged the Lutheran understanding of freedom, Scripture, faith and grace in salvation that he was able to hope for the salvation of all. In parallel with this it was precisely because his opponents had not fully grasped his arguments that they assumed that they entailed the positive assertion that all would be saved.

In conclusion, then, it is easy to see how Denck could be accused of being a universalist. His written works do not deny universalism explicitly and his theology certainly admits the possibility that all people will be saved. Denck was clearly influenced by ideas which can be described as broadly Origenistic particularly freedom, divinisation and the temporary, reformatory nature of some divine punishment - which might tempt opponents to attribute further Origenistic ideas to him. Finally, those of his opponents who held strong Lutheran beliefs in predestination, the lack of true human freedom and the nature of Christ's atonement would have found it genuinely difficult to understand how one could claim on the one hand that God wills all to be saved, Christ died for all and all are free, and on the other that some people may escape salvation. Thus, although Hans Denck probably never asserted that all humanity would certainly be saved he clearly hoped for this outcome, and that was enough in many people's eyes to justify their accusations of universalism.

Furthermore, it is clear that it was not just this hope in itself that angered his opponents, but rather the presuppositions on which it was based, which challenged some of the core aspects of mainstream Reformation thought on Christ's work, the power of Scripture and the nature of grace, sin and the human will. This episode is thus a useful reminder of the radical theological challenge which thinkers and preachers like Denck presented.

77 Interestingly, there was a distinct tradition of universalism among former Calvinists which arose from a repugnance at the idea of God predestining people to hell but which retained the ideas of predestination to heaven and penal substitutionary interpretation of the atonement, but Denck himself does not follow this line. Geoffrey Rowell describes this position as 'faith by compulsory justification': this JouRnaL xxii (I97I), 55 .

78 Bucer, Getrewe warnung, 235, cited by Walter Fellmann in 'Martin Bucer und Hans Denck', Mennonitische Geschichtsblätter xxiii (I966), 30. 
More broadly, Denck's case also provides a useful example of two interconnected phenomena of the rhetoric of theological debate: first, the tendency to associate one's opponents with a known heresy and secondly the tendency to associate a doctrine which one holds to be false with a group which is famously supposed to be extreme or heretical. Thus Denck's opponents tried to discredit him by associating him with an Origenistic form of universalism (which was condemned by the Fifth Ecumenical Council in 553). Subsequently, this association plus the notoriously exaggerated reputation of so-called 'anabaptists' for violent extremism was used to weaken claims that universalism could be part of mainstream Christian doctrine. Indeed, the validity of the doctrine of universal salvation is still being debated by systematic theologians in terms not dissimilar to those used in the sixteenth century. It is striking and instructive that, for example, the ideas of a universal atonement and a universal salvation are still often confused and that some modern theologians are heavily criticised, as Denck was, for trying to explain how grace might be accessible to those who do not encounter the Gospel in its written or preached forms. Given these facts, it is perhaps not surprising that not only is Denck still thought to have been a universalist, but that other theologians whose thought has tended in a similar direction have also had the same claim made of them. 